\title{
Phylogenetic characteristics of novel Bacillus weihenstephanensis and Pseudomonas sp. to desert locust, Schistocerca gregaria Forskål (Orthoptera: Acrididae)
}

\author{
Tamer A. Mashtoly ${ }^{1 *}$ (D), Mohamed S. El-Zemaity ${ }^{1}$, Assem Abolmaaty ${ }^{2}$, Gamal M. Abdelatef ${ }^{3}$, Ashraf A. Marzouk ${ }^{4}$ and \\ Mohamed Reda ${ }^{3}$
}

\begin{abstract}
Thirty bacterial isolates were isolated from the gut contents of diseased/dead locust. Their pathogenicity was tested against 4th instar nymphs of desert locust, Schistocerca gregaria Forskål (Orthoptera: Acrididae). Two isolates, designated DL2 and DL6, out of thirty showed the highest insecticidal activities against locust nymphs in preliminary bracketing. They were bioassayed via leaf dip and per os techniques and toxicity was determined using SAS program. The insecticidal activity of DL6 was more than DL2, whereas $L C_{50}$ 's values of $35 \times 10^{6}$ and $13 \times 10^{6} \mathrm{cfu}$ 's $/ \mathrm{ml}$ were determined for DL2 and DL6, respectively, after $48 \mathrm{~h}$ of leaf-dip treatment. However, $\mathrm{LD}_{50}$ 's value of $53 \times 10^{6}$ and $26 \times 10^{6} \mathrm{cfu}$ 's $/ \mathrm{ml}$ was determined for DL2 and DL6, respectively, after $24 \mathrm{~h}$ of per os treatment. The relative potencies of DL6 to DL2 were (2.6 and 2.03) folds in leaf-dip and per os treatments, respectively. Biochemical characterization was conducted, using GEN III MicroPlate ${ }^{\mathrm{TM}}$ Biolog identification system and confirmed with molecular identification via 165 rDNA gene sequencing. Nucleotide sequencing of each was submitted to a gene bank and an accession number was generated for each isolate. Obtained bacterial strains DL2 and DL6 were identified as Bacillus weihenstephanensis (KY630645) and Pseudomonas sp. (KY630649), with a similarity of 100 and 75\% to B. weihenstephanensis strain PHCDB9 (NR_024697) and Pseudomonas sp. strain DSM11821 (KF417541), respectively. The tested strains proved their potential to be bio-pesticide agents involved in controlling desert locust nymphs.
\end{abstract}

Keywords: Desert locust, Entomopathogenic bacteria, Microbial control, Microbial identification, 16S rRNA genes sequencing, Biolog identification system, Bio-pesticides

\section{Background}

Locust swarms are considered to be a dramatic severe threat to sustainable food production globally (Lecoq, 2001). A lot of environmental concerns have been raised about the adverse impacts of the chemical pesticides used in controlling locusts. These concerns have drawn attention to the importance of developing biocontrol agents against locusts. Entomopathogenic bacteria such as Bacillus spp. possess antagonistic effects as pesticide

\footnotetext{
* Correspondence: telmashtoly@agr.asu.edu.eg; sammashtoly@yahoo.com ${ }^{1}$ Department of Plant Protection, Faculty of Agriculture, Ain Shams University, P.O.Box: 68 Hadayek Shoubra, Cairo 11241, Egypt

Full list of author information is available at the end of the article
}

either killer and/or antifungal agents (Mashtoly et al., 2009 and Mardanova et al., 2017). Many known Cry toxins have been produced from numerous Bacillus thuringiensis strains, efficiently initiating ion imbalance in brush border membrane vesicles (BBMVs) as a step in causing sepsis and then death (Bravo et al., 2013). Most of them are effective in alkaline $\mathrm{pH}$ gut conditions in lepidopteran insects. Some other Bacillus spp. such as Bacillus cereus, B. subtilis, B. sphaericus, and B. weihenstephanensis have the ability to produce antifungal compounds such as cyclic lipopeptides, polyketide synthases (PKS), or mycolytic enzymes like chitinases (Swiontek Brzezinska et al., 2014 and Aleti et al., 2015). Moreover, 
B. weihenstephanensis was reported as the only species to grow in psychrophilic conditions (Lechner, et al., 1998).

Most entomopathogenic bacteria are spore forming which count on Cry toxins to cause insect mortality. Some non-spore forming bacteria such as Pseudomonas spp. exhibited different virulence factors encoded in their excretions. Pathogenicity of $P$. aeruginosa Schroeder and $P$. chlororaphis (Gignard and Sauvageau) were investigated as efficient microbial agents in controlling some insect species including Acridoidea (Latchininsky et al., 2002). $P$. entomophila exhibited unique pathogenic characterization to lepidopteran, dipteran, and coleopteran insects (ValletGely et al., 2010). Usually, the insecticidal characteristics of non-spore forming bacteria to insects depend on the capability of the entomopathogen to enter, survive, persist in mid-gut physicochemical conditions and immune defenses, and excrete toxic substances that disrupt host physiology (Dieppois, et al. 2015).

Different reports indicate that the desert locust, Schistocerca gregaria, (Forskål) (Orthoptera: Acrididae) consumes approximately its own weight ( $2 \mathrm{~g}$ as adults) of fresh vegetation each day. Swarms often contain 50 million individuals per $\mathrm{km}^{2}$ so that even a moderate swarm measuring $10 \mathrm{~km}^{2}$ could consume about 1000 tons of fresh vegetation daily during migration (COPR (Centre of Overseas Pest Research), 1982). Periodic outbreaks of locusts are a threat to agricultural production in several countries (Szabo et al., 2003).

The present study aimed to isolate and investigate the toxicities of entomopathogenic bacteria from infected/ dead locust nymphs. Phenotypic characterization and molecular identification were conducted for antagonistic isolates which may have the potential to be efficient biocontrol agents for desert locust.

\section{Materials and methods Insects}

A culture of the desert locust, S. gregaria, was maintained in a laboratory at the Department of Locust and Grasshoppers Research, Plant Protection Research Institute, Agricultural Research Center, Giza, Egypt. The culture was examined daily for either dead or diseased insects, which were placed individually in separate sterile tubes. Diseased insects were lethargic and showed signs of bacterial infection such as a reddish or brown color on the thorax or abdomen along with flaccid bodies. Therefore, they were transferred to the Microbiological Resource Centre (MIRCEN) at the Faculty of Agriculture, Ain Shams University, Cairo, Egypt, for identification and bioassays.

\section{Isolation of bacteria}

Infected insects were dissected under sterile conditions. Individual swabs from the gut and dead locust paste (resulted from grinding the dead locusts in a sterilized phosphate buffer) were directly streaked on Tryptone Soy Agar Petri dishes (TSA) and incubated at $30{ }^{\circ} \mathrm{C} / 72$ h. Bacterial isolates were separated and picked up based on morphological characteristics such as colony shape and color. Streaking was repeated about 6 times for each isolate until pure colonies were obtained. Purified isolates were examined microscopically for parasporal inclusions and gram staining then subjected to preliminary bioassay.

\section{Cultivation of bacterial isolates}

One hundred milliliters of Tryptone Soy broth (TSB) in 250-ml baffled flasks was inoculated with individual purified bacterial isolate and incubated overnight at 30 ${ }^{\circ} \mathrm{C}$ with rotary agitation $(150 \mathrm{rpm})$. Exponentially growing cells $\left(\sim 1 \times 10^{6}\right.$ cells $\left./ \mathrm{ml}\right)$ were harvested by centrifuging broth culture at $4000 \mathrm{rpm} / 15 \mathrm{~min} / 4{ }^{\circ} \mathrm{C}$ and the supernatants were discarded. Pellets of each isolate were washed 3 times by sterile phosphate buffer saline (PBS) and then suspended in $40 \mathrm{ml}$ PBS. Absorbance of turbidity was measured at $600 \mathrm{~nm}$ for stock solution and its serial dilutions. A plate count of each isolate was carried out in Tryptone Soy Agar plates by inoculating $100 \mu \mathrm{l}$ of each serial dilution per plate. All measures were conducted three times and the mean values were used to generate colony-forming units (cfu's) that correspond to the turbidity absorption at $600 \mathrm{~nm}$ after $48 \mathrm{~h}$ at $30{ }^{\circ} \mathrm{C}$. Bacterial suspensions used in preliminary screening and bioassays were expressed as cfu's $/ \mathrm{ml}$.

\section{Screening for bioactive bacterial isolates against locust}

All isolates were subjected to preliminary bioassay for screening the bioactive isolates, using prepared stock solutions $\left(\sim 1 \times 10^{6}\right.$ cells $\left./ \mathrm{ml}\right)$. Fresh sticks and leaves of Egyptian clover were immersed in each bacterial suspension individually for $3 \mathrm{~min}$, then allowed to dry under ambient temperature for about $10 \mathrm{~min}$. Treated sticks and leaves of Egyptian clover were introduced as solo feed to five 4th instar nymphs of desert locust. Treated insects were placed individually in plastic boxes $(30 \times 18$ $\mathrm{cm})$. Daily inspection was continued up to 10 days and mortalities were recorded. Two bacterial isolates designated DL2 and DL6 proved an insecticidal activity to locust nymphs and were subjected to bioassay and molecular identification using $16 \mathrm{~S}$ rRNA gene sequencing.

\section{Morphological analysis}

Pure colonies of the selected bacterial isolates were subjected to gram stain and examined for spores and crystals. One hundred milliliters of Tryptone Soy broth media were inoculated by one loop of each bacterial isolate and incubated at $30{ }^{\circ} \mathrm{C}$ with rotary agitation 150 rpm for 96 h. Fifty microliters of each suspension were 
checked, by oil emersion $\times 100$ lens of light microscope, for crystal protein and inclusion bodies.

\section{Bioassay}

Insecticidal activity of preliminary selected isolates was assessed for 4th instar nymphs of desert locust using leaf-dipping and per os techniques.

\section{Leaf dipping technique}

Serial dilutions of the selected bacterial isolates, Dl2 and DL6, were prepared in autoclaved phosphate buffer saline (1X PBS) under aseptic conditions. Colony-forming units per milliliter for all suspensions were adjusted (Table 1). Fresh stems and leaves of Egyptian clover were immersed entirely with gentle agitation in each bacterial suspension and in autoclaved $1 \mathrm{X}$ PBS, as control treatment for $3 \mathrm{~min}$ and then dried at ambient temperature for about $10 \mathrm{~min}$. Stems and leaves treated with the same isolate were introduced as solo feed to three replicates of ten 4th instar nymphs individually and then kept in individual small wooden framed $(30 \mathrm{~cm}$ in length, $18 \mathrm{~cm}$ in width, and $20 \mathrm{~cm}$ in height) cages equipped with wire gauze in front and top for easy access. Replicates of treatments and control were kept under the same rearing conditions (cages illuminated with 100 watts electric bulbs in winter and 75 watts electric bulbs in summer, $31 \pm 2{ }^{\circ} \mathrm{C}$ and $50-70 \%$ R.H.) in the laboratory. Mortalities were examined daily and subjected to statistical probit analysis.

\section{Per os technique}

Serial dilutions of the two selected bacterial isolates, DL2 and DL6, were prepared in autoclaved phosphate buffer saline (1X PBS) under aseptic conditions. Cell suspensions were adjusted in (cfu's/ml) (Table 2). Two hundred microliters of each dilution were administered per os via $1-\mathrm{cm}$ Hamilton syringe equipped with 27 gauge needle to ten 4th instar nymphs of $S$. gregaria and each of them was used as individual replicate. Control trial followed the same procedure, except using autoclaved 1X PBS instead of the bacterial suspension. Mortalities were recorded and subjected to statistical probit analysis.

Table 1 Preparation of different cell concentration (cfu's/ml) of the two selected isolates for leaf dipping bioassay technique

\begin{tabular}{llllll}
\hline Strains & $\begin{array}{l}\text { Stock suspension } \\
\text { (cfu's/ml) }\end{array}$ & \multicolumn{4}{l}{ Dilutions (cfu's/ml) } \\
\cline { 3 - 6 } & & 1 & 2 & 3 & 4 \\
\hline DL2 & $29.8 \times 10^{6}$ & $14.9 \times 10^{6}$ & $7.4 \times 10^{6}$ & $3.7 \times 10^{6}$ & $1.5 \times 10^{6}$ \\
DL6 & $131 \times 10^{6}$ & $65 \times 10^{6}$ & $32 \times 10^{6}$ & $16 \times 10^{6}$ & $8 \times 10^{6}$ \\
\hline
\end{tabular}

Table 2 Preparation of different cell concentration (cfu's/ml) of the two selected isolates for per os bioassay technique

\begin{tabular}{llllll}
\hline Strains & $\begin{array}{l}\text { Stock suspension } \\
\text { (cfu's/ml) }\end{array}$ & \multicolumn{4}{l}{ Dilutions (cfu's/ml) } \\
\cline { 3 - 6 } & & \multicolumn{2}{l}{2} & 3 & 4 \\
\hline DL2 & $59.7 \times 10^{6}$ & $29.8 \times 10^{6}$ & $14.9 \times 10^{6}$ & $7.4 \times 10^{6}$ & $3.7 \times 10^{6}$ \\
DL6 & $295 \times 10^{6}$ & $147 \times 10^{6}$ & $73 \times 10^{6}$ & $36 \times 10^{6}$ & $18 \times 10^{6}$ \\
\hline
\end{tabular}

\section{Statistical analysis}

Recorded mortalities of replicates in each concentration were pooled together and statistically analysed via PROC-PROBIT analysis system version 9.4 (SAS Institute 2012). $\mathrm{LC}_{50}$ 's values were compared and a failure of $95 \%$ $\mathrm{CL}$ to overlap was used as a measure of significant differences between treatments. In All cases, the likelihood ratio (L.R) chi-square goodness-of-fit values indicated that data adequately conformed to the probit model (Robertson and Preisler 1992).

\section{Biochemical identification of bacterial isolates}

Preliminary biochemical and phenotypic characterizations of the selected two bacterial isolates (DL2 and DL6) were conducted using the GEN III Biolog Microplates $^{\text {tix }}$ identification system at the Microbial Resources Centre (MIRCEN) (data not shown). Bacterial suspensions were prepared using the manufacturer's instructions and then inoculated into 96-well microplates, incorporated with redox tetrazolium dye, and incubated. Cellular respiration was resulted in changing colors due to the unique metabolic fingerprint of each bacterial strain. Microplates were read and compared to the extensive databases incorporated in OmniLog ID System.

\section{$16 S$ rDNA gene sequencing for bacterial identification \\ Extraction of bacterial DNA}

Pure individual colonies of DL2 and DL6 were picked up by a sterilized toothpick and suspended separately in $500 \mu \mathrm{l}$ of sterilized phosphate buffer saline 1X (PBS 1x) in a $1500-\mu \mathrm{l}$ centrifuge tube. Each tube was centrifuged at $10,000 \mathrm{rpm}$ for $10 \mathrm{~min}$ using a micro-centrifuge. Supernatant was drawn off and the pellet was suspended in $500 \mu \mathrm{l}$ of Genomic DNA Extraction Kit (Thermo Fisher Scientific Inc., Waltham, MA, USA). The suspension was incubated at $65{ }^{\circ} \mathrm{C}$ for $30 \mathrm{~min}$ and then heated to $100{ }^{\circ} \mathrm{C}$ for $10 \mathrm{~min}$ and finally cooled to $5{ }^{\circ} \mathrm{C}$ on ice and subjected to PCR.

\section{Amplification of $16 \mathrm{~S}$ rDNA}

One set of universal primers (Integrated DNA Technologies, Inc., Mbiotech, Inc. South Korea) 27F (5'-AGA GTT TGA TCM TGG CTC AG-3'); 1492R (5'-TAC GGY TAC CTT GTT ACG ACT T-3') was used to amplify the 
targeted 16S rRNA gene. The final standard PCR mixture consisted of $45 \mu \mathrm{l}$ of Platinum PCR Super Mix 1.1X (Invitrogen Corp., USA) and contains anti-TaqDNA polymerase antibody, $\mathrm{Mg}^{2+} \mathrm{dNTPs}$, and recombinant TaqDNA polymerase at concentrations sufficient to allow amplification during PCR. One microliter of one forward and one reverse primer and $3 \mu \mathrm{l}$ of targeted bacterial DNA at the level of $1 \times 10^{8}$ templates were added to $45 \mu \mathrm{l}$ of the standard PCR SuperMix in a final volume of $50 \mu \mathrm{l}$. PCR vials were placed in a C1000 Touch ${ }^{\mathrm{TM}}$ Thermal Cycler (Bio-Rad Laboratories, Inc.) which is fully programmable thermal cycler used for fast PCR reactions. The cycling protocol used consisted of initial denaturation at $95^{\circ} \mathrm{C}$ for $3 \mathrm{~min}$, followed by 45 denaturation cycles for $55 \mathrm{~s}$ at $94{ }^{\circ} \mathrm{C}$, annealing at $55{ }^{\circ} \mathrm{C}$ for $40 \mathrm{~s}$, and elongation at $72{ }^{\circ} \mathrm{C}$ for $90 \mathrm{~s}$. Final elongation was performed at $72{ }^{\circ} \mathrm{C}$ for $600 \mathrm{~s}$. Blanks consisted of all components of the reaction mixture except the substrate (DNA of the bacterial isolate). PCR products were subjected to $2 \%$ agarose gel electrophoreses stained with $5 \mu \mathrm{l}$ of $\mathrm{SYBR}^{\circ}$ safe DNA gel stain "10.000X concentrate in dimethyl sulfoxide (DMSO) (Invitrogen Corp, USA.) in running buffer $(0.2 \mathrm{M}$ Tris base, $0.1 \mathrm{M}$ Sodium acetate, $0.01 \mathrm{M} \mathrm{Na}_{2}$.EDTA, at $\mathrm{pH}$ 7.8). Digital images were taken by a Gel $\operatorname{Doc}^{\mathrm{mm}} \mathrm{EZ}$ Gel Documentation System (Bio-Rad Laboratories, Inc.).

\section{Purification of PCR product}

Clear bands of bacterial DNA appeared with no background on agarose gel electrophoresis confirmed the purity of yielded DNA prior to amplification. PCR products were purified from unwanted primers and impurities such as salts, enzymes, and unincorporated nucleotides, using a QIAquick PCR purification kit (Qiagen), following the manufacturer's instructions via spin column technology optimized by uniquely designed silica membrane and three different functional buffers: binding buffer for binding of DNA in high-salt buffer, washing buffer for washing away all the impurities, and pure DNA was eluted with $30 \mu \mathrm{l}$ of low-salt elution buffer $(10 \mathrm{mM}$ Tris $\mathrm{Cl}$, $\mathrm{pH}$ 8.5) for high efficient recovery of DNA. The absorbance ratio of $260 / 280$ of the purified DNA was determined, using a Smart Spec $^{\text {Tw }}$ Plus spectrophotometer (Bio-Rad Laboratories, Inc.) and conformed the high purity of yielded DNA.

\section{Gene sequencing and phylogenetic analysis}

Purified bacterial DNA was diluted to $5 \mathrm{ng} / \mu \mathrm{l}$ of DNA with DNAase and RNAase free water and then each sample was divided into two samples. One set of universal primers (Integrated DNA Technologies, Inc., Mbiotech, Inc. South Korea) 518F (5'-CCA GCA GCC GCG GTA ATA CG-3') and 800R (5'-TAC CAG GGT ATC TAA TCC-3'), was used for DNA sequencing. Sequencing of the purified DNA of approximately $1000-1100$ bp was conducted via Macrogen sequencing service (Macrogen, Inc., Korea), using Big Dye terminator cycle sequencing kit and resolved on automated DNA sequencing systems model 3730XL and then analyzed by Sequence Scanner Version 1.0 @ 2005 (Applied Biosystems, USA). 16S rRNA sequences of our isolates DL2 and DL6 were blasted and compared to other 16S rRNA sequences on the National Centre for Biotechnology Information (NCBI) database at https://www.ncbi.nlm.nih.gov/ (Altschul et al., 1990). Alignment of multiple sequences was examined against corresponding nucleotide sequences using the CLUSTAL W Program (Thompson et al, 1994) for proper matches with known species. Sequence analysis and phylogenetic tree were generated and constructed using the Molecular Evolutionary Genetics Analysis (MEGA) software version 7.0.

\section{Results and discussion}

Isolation of the entomopathogenic bacteria from the diseased and dead locusts resulted in thirty different purified bacterial strains, isolated from the gut and the dead locust paste (data not shown). The bioactivity of each bacterial isolate was tested via preliminary bracketing bioassay against 4 th instar nymphs $S$. gregaria. Two bacterial isolates, designated DL2 and DL6, out of thirty showed significant antagonistic impacts to tested nymphs. The morphological examination of bioactive purified isolates via light microscope confirmed that DL2 isolate was a spore-forming, gram-positive bacteria, while DL6 was non-spore-forming, gram-negative bacteria. Neither DL2 nor DL6 had the ability to produce inclusion bodies or crystal protein.

\section{Susceptibility of 4 th instar nymphs of $S$. gregaria to the selected isolated bacteria}

A preliminary bracketing bioassay revealed that 4th instar nymphs were highly susceptible and showed higher mortality rates to isolates DL2 and DL6 than any others. Moreover, leaf dipping bioassays showed that DL2 and DL6 were highly effective biocontrol agents, causing death to treated nymphs. After $48 \mathrm{~h}$, data demonstrated that $\mathrm{LC}_{50}$ 's values of $35 \times 10^{6}$ and $13 \times 10^{6} \mathrm{cfu}$ 's $/ \mathrm{ml}$ were determined for DL2 and DL6, respectively (Table 3). Per os treatment showed the same trend of results, where DL2 and DL6 were the most efficient isolates. Data in Table 4 showed $\mathrm{LD}_{50}$ 's values of $53 \times 10^{6}$ and $26 \times 10^{6}$ cfu's/ml for DL2 and DL6, respectively. Mean values of mortality rates in control treatments were 4.2 and $6.6 \%$ for leaf-dip and per os treatments, respectively.

Data in Table 3 indicated that isolate DL6 was more effective than DL2. Failure of overlap at 95\% fiducial limits was considered as an evidence for significant differences between $\mathrm{LC}_{50}$ levels. The toxicity index values from the leaf-dip bioassay illustrated the relative potency between the most efficient isolate (DL6) as a standard 
Table 3 Toxicity values of DL2 and DL6 isolates to 4th instar nymphs of Schistocerca gregaria using leaf dipping bioassay technique

\begin{tabular}{lllllll}
\hline Isolate & $\mathrm{N}$ & Slope (SE) & $\mathrm{LC}_{50}{ }^{\mathrm{ab}}$ & $x^{2}(\mathrm{df})^{\mathrm{c}}$ & $95 \% \mathrm{FL}$ & Toxicity index $^{\mathrm{d}}$ \\
\hline DL2 & 180 & $2.19(0.35)$ & $35 \times 10^{6} \mathrm{~b}$ & $1.65(3)$ & $25 \times 10^{6}-45 \times 10^{6}$ & 37.14 \\
DL6 & 180 & $1.19(0.26)$ & $13 \times 10^{6} \mathrm{a}$ & $1.92(3)$ & $60 \times 10^{5}-20 \times 10^{6}$ & 100 \\
\hline
\end{tabular}

${ }^{\mathrm{a} L C_{50}}$ 's reported in cfu's

${ }^{\mathrm{b}} \mathrm{LC} \mathrm{C}_{50}$ 's followed by the same letter are not significantly different based on overlap of their $95 \%$ fiducial limits $(P<0.05)$

'L.R. chi-square goodness-of-fit values. Tabular values at $P=0.05$ for $3 \mathrm{df}=7.81$

${ }^{\mathrm{d}}$ Toxicity index (Sun, 1950$)=\left(\mathrm{LC}_{50}\right.$ of the most efficient compound (as Standard) $/ \mathrm{LC}_{50}$ of the other tested compound) $* 100$

$N$ refers to total number of insects in treatment

and the other isolate DL2 (Sun, 1950). The potency of DL6 was approximately 2.6 folds than that of DL2 (Table 3). On the other hand, per os bioassay in Table 4 revealed a similar trend of efficacy, whereas DL6 had toxicity 2.03-folds of DL2. However, there was insignificant difference shown between DL2 and DL6 in per os bioassay, whereas an overlap occurred between the fiducial limits.

Although entomopathogenic bacteria are well known as the most efficient bio agents in controlling insects, Pseudomonas aeruginosa was the first bacterial isolate registered against the desert locusts (Ashrafi, et al, 1965). Obtained bacterial isolates may become promising entomopathogenic bacteria to control S. gregaria nymphs due to their fast killing rate.

\section{Biochemical characterizations of selected bacteria using Biolog microbial identification system}

Biolog MicroPlate ${ }^{\mathrm{TM}}$ pattern revealed that the most bioactive bacterial isolates, DL2 and DL6, to 4th instar nymphs of $S$. gregaria were preliminary identified as $B$. weihenstephanensis and Pseudomonas sp., respectively, according to their metabolic fingerprint.

\section{Molecular identification of the most bioactive bacterial isolates using $16 \mathrm{~S}$ rRNA sequencing}

Images captured of agarose gel electrophoreses (Fig. 1) emphasized that the isolation process of DL2 and DL6 from the gut and paste of the infected/dead locusts was successfully conducted under aseptic and controlled conditions. The yielded bands were about 1000 to 1100 bp, for DL2 and DL6 isolates, respectively. DNA amplification and DNA sequencing were conducted using two sets of primers that were designed to complement the conserved regions of $16 \mathrm{~S}$ ribosomal DNA of both DL2 and DL6 strains. The genera Bacillus and Pseudomonas were found to be the predominant identified bacteria, when sequences were blasted against nucleotide database using a nucleotide query algorithm.

The following partial 16S rRNA gene sequence is already submitted to NCBI under the accession number KY630645 and KY630649 for DL2 and DL6, respectively, as the following:

https://www.ncbi.nlm.nih.gov/nuccore/KY630645)

https://www.ncbi.nlm.nih.gov/nuccore/KY630649

Partial sequence of DL2, 409 bp

"GGAGCAGAGTGACAGGTGGTGCATGGTTGTCG

TCAGCTCGTGTCGTGAGATGTTGGGTTAAGTCCC

GCAACGAGCGCAACCCTTGATCTTAGTTGCCAT

CATTAAGTTGGGCACTCTAAGGTGACTGCCGGT

GACAAACCGGAGGAAGGTGGGGATGACGTCAAT

CATCATGCCCCTTATGACCTGGGCTACACACGTG

CTACAATGGACGGTACAAAGAGCTGCAAGACCG

CGAGGTGGAGCTAATCTCATAAAACCGCTCTCAG

TTCGGATTGTAGG

CTGCAACTCGCCTACATGAAGCTGGAATCGCTA GTAATCGCGGATCAGCATGCCGCGGTGAATACG TTCCCGGGCCTTGTACACACCGCCCGTCACAC CACGAGAGTTTGTAACACCCGAAGTCGGTGG ${ }^{\text {ee }}$

Partial sequence of DL6, $669 \mathrm{bp}$

"GGAGCTAACGCGTTAAGTTCACCGCCTGGGGA GTACGGCCGCAAGACTGAACCTCAATGGATTTG ACGGGGGCCCCCGCAACCGGGGAACTAGGTGGT TTATTTCAAGCCACCCCGAAAACCCTTACCTCGC CTTGCCTCGTCAAAAACTTTCCAAAAATGGATGG TGGCCTTCGGAACCCCGAAACCAGGGCCTGCTTG

Table 4 Toxicity values of DL2 and DL6 isolates to 4th instar nymphs of Schistocerca gregaria using per os bioassay technique

\begin{tabular}{lllllll}
\hline Isolate & $N$ & Slope $(\mathrm{SE})$ & $\mathrm{LD}_{50} \mathrm{ab}^{\mathrm{ab}}$ & $x^{2}(\mathrm{df})^{\mathrm{c}}$ & $95 \% \mathrm{FL}$ & Toxicity index $^{\mathrm{d}}$ \\
\hline DL2 & 30 & $1.64(0.77)$ & $53 \times 10^{6} \mathrm{a}$ & $0.80(3)$ & $68 \times 10^{2}-12 \times 10^{8}$ & 49.05 \\
DL6 & 30 & $1.64(0.77)$ & $26 \times 10^{6} \mathrm{a}$ & $0.80(3)$ & $33 \times 10^{2}-59 \times 10^{6}$ & 100 \\
\hline
\end{tabular}

${ }^{\mathrm{a}} \mathrm{LD}_{50}$ 's reported in cfu's

${ }^{b} \mathrm{LD}_{50}$ 's followed by the same letter are not significantly different based on overlap of their $95 \%$ fiducial limits $(P<0.05)$

'L.R. chi-square goodness-of-fit values. Tabular values at $P=0.05$ for $3 \mathrm{df}=7.81$

d Toxicity index (Sun, 1950$)=\left(L C_{50}\right.$ of the most efficient compound (as standard) $/ L_{50}$ of the other tested compound) $* 100$

$N$ refers to total number of insects in treatment 


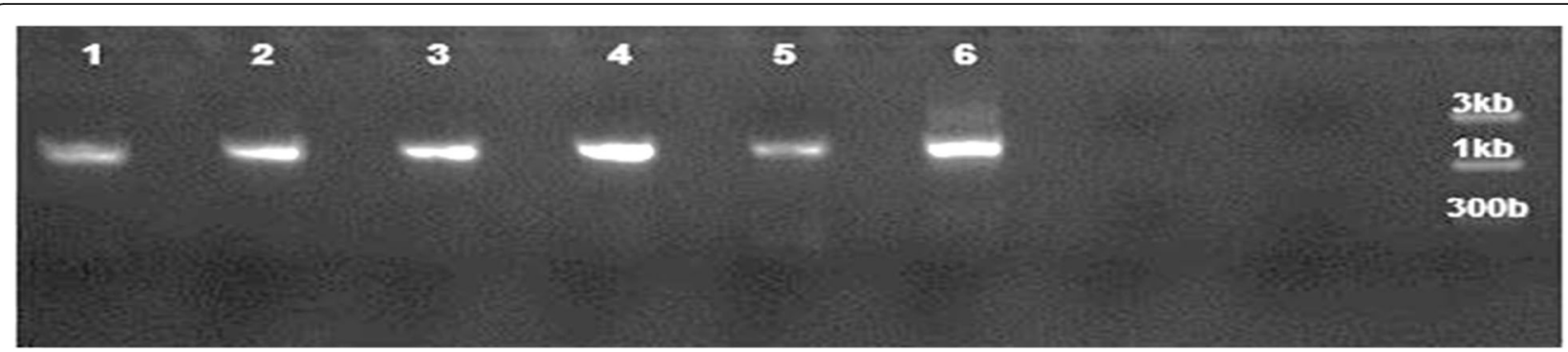

Fig. 1 Gel electrophoresis of 2\% agarose gel illustrating the amplification of partial 16S rRNA genes of isolates DL2 and DL6 (lanes 2 and 6, respectively)

GTTGCCTCCACCTCTGGTCTGGAAAGGTGGGGTT AAGTCCCCCCACCAACGCACCCCTTGCCCTTGTT TGCCACCGCTCAAAGCCGGGGAATCTCAAGAGA CAGCCCCTGAGACACTCCAGAAAAGGGGGGATC ACCTCGTCTCCTCGGGCCCCTTAAGGACGGGGCT ACACGCGCTCTACTGGGGTATGCACAGAGGAC TGCACCCCCGCAAGCGAACGCACCTCCCAAAATC CCTCTCACACCCGAGAGTAGACTCTGCAACTCTA CTCTCTGAAATCTCAAACTCTCTTAATCACATAT CAACGTTGCTGCGAAGACTATCTCCGCGGGTGTT GTCCACGCCCGCCGTCCCACCGGGGGTAGTTTGT TGCACCAGAAGCATGTAGCTTCTCCTTCCAGGAG GCCGCTCGCCTCGGGATGCCCGACTACTGGGAA GACCTCAAGAAGGGGCCCCCCAAAAAAAAAAA".

The isolated bacteria DL2 and DL6 were successfully identified as B. weihenstephanensis (KY6306 45) and Pseudomonas sp. (KY630649), with a very high similarity of $100 \%$ with B. weihenstephanensis strain PHCDB9 (NR_024697) and 75\% with Pseudomonas sp. strain DSM11821 (KF417541), respectively.

The genus Bacillus has been considered as proteolytic bacteria (Visotto et al., 2009), enhancing toxicity agent (Mashtoly et al., 2010 \& Mashtoly et al., 2011), and/or entomopathogenic bacteria (Sezen et al., 2005 and Mashtoly et al., 2009). Insecticidal characteristics of Bacillus spp. varied due to the ability in producing their entomopathogenic toxins. Bacillus cereus group includes six related species such as $B$. cereus, $B$. anthracis, $B$. thuringiensis, B. mycoides, B. pseudomycoides, and $B$. weihenstephanensis have been known to produce a lipase toxin namely phospholipase C (Lysenko 1972a, b) and the paralytic toxin sphingomyelinase $\mathrm{C}$ (Nishiwaki et al., 2004). B. thuringiensis has been considered the most attributed entomopathogenic bacteria in controlling insects. $B$. weihenstephanensis is known with a unique capability to survive in a psychrophilic condition (Soufiane and Cote, 2010). B. thuringiensis serovar japonensis and $B$. cereus have been successfully used as microbial control agents for the grubs of Anomala orientalis, Cyclocephala borealis, Amphimallon solstitialis, Melolontha melolontha, Anomala dimidiata, and Holotrichia seticollis (Guttmann and Ellar, 2000; Mashtoly, et al., 2010; Selvakumar et al., 2007 and Sushil et al., 2008).

In our previous research, two different strains of $B$. cereus causing significant mortality rates to the desert locust were identified (Reda et al., 2018) and both strains might be involved as integrated agents into locust management systems to protect the environment and wildlife from chemical use. B. weihenstephanensis and B. thuringiensis, in particular, and the crystal proteins of $B$. thuringiensis were found to be antagonist to $M$. melolontha larvae. $B$. weihenstephanensis showed $80 \%$ insecticidal activity, which proved its ability to be a significant biological control agent (Sezen et al., 2007).

The insecticidal effects of $P$. fluorescens, $P$. aeruginosa, and $P$. chlororaphis have been reported to different pests such as M. melolontha larvae (Coleoptera: Scarabaeidae), (Osborn et al., 2002; Bucher, 1981; Sezen and Demirbag 1999). Pseudomonas sp. showed significant efficacy in controlling locust nymphs. Moreover, they displayed specific characteristic features of sepsis that appeared in thinning out of the internals and body skeletal, often with a specific rancid smell (Dieppois et al., 2015). The mortality rate of $L$. migratoria infected with Pseudomonas sp. was approximately (30-50\%) within 3 to 7 days after treatment (Lednev et al., 2008). P. entomophila exhibited a unique characterization which demonstrated specific pathogenic properties to dipteran, lepidopteran, and coleopteran insects (Vodovar et al. 2005; Vallet-Gely et al. 2010).

Most entomopathogenic bacteria are spore forming counting on Cry toxins in causing insect mortality. However, there are non-spore-forming bacteria, such as Pseudomonas spp., that exhibit virulence factors encoded in their excretions. The insecticidal properties of nonspore-forming bacteria to insects often vary upon their capability to enter, persist, and survive in the gut physicochemical conditions and be protected from the gut immune defense system as well. Thus, the excretion of toxic substances may disrupt the host's physiology (Dieppois et al., 2015). Obtained results indicate that the strains B. weihenstephanensis and Pseudomonas sp. have a significant impact as biocontrol agents, causing 
nymphocidal activity to desert locusts. Further research is needed to investigate the whole characterization profile and host range of these isolates.

Attention has been drawn to the Biolog System ${ }^{\mathrm{Tw}}$ (Biolog, Inc., Hayward, CA) as one of the most developed reliable technologies for rapid identifying and characterizing the environmental microbes (Al-Dhabaan and Bakhali, 2017). Carbon source utilization was the fundamental reaction that Biolog system counted on via exchange of the generated electrons during respirations through oxidizing colorimetric reaction. Such color and colorless pattern in 96-well microplates expressed the metabolic fingerprint of the tested microorganism (Miller and Rhoden, 1991). Evaluations of this biochemical identification tool resulted in precise, reproducible, and comprehensive bacterial characterizations (Chojniak et al., 2015). Potential difficulties and overlaps in phenotypic identification of some bacteria could occur and 16S ribosomal DNA-based identification of unknown bacteria has been widely applied as a reliable accurate tool (Drancourt et al., 2000). Universal identification methods based on general primer mixture was evaluated and validated for amplification of any bacterial DNA (Barghouthi, 2011). Sequenced 16S rDNA subjected to BLAST (Basic Local Alignment Search Tool) web-based program for alignment the obtained sequence to thousands of different sequences in the National Centre for Biotechnology Information (NCBI) at https://www. ncbi.nlm.nih.gov/ (Altschul et al., 1990). It is of interest to note that 405 and 502 bp of the DL2 and DL6 sequences were highly aligned $(100 \%)$ when they were tested with BLASTn, nucleotide alignment (bl2seq). This $100 \%$ identity indicated that PCR product was almost fully sequenced. Therefore, our bacterial isolates were identified as B. weihenstephanensis strain and Pseudomonas sp. strain for DL2 and DL6, respectively. Therefore, genotyping via $16 \mathrm{~S}$ rRNA sequencing confirmed the phenotypic biochemical characterizations via Biolog system at the species level.
Phylogenetic analysis was inferred the inter-relationships between the identified bacterium and the existing relatives on Genbank based on 16S rRNA gene sequencing (Weisburg et al., 1991). Phylogenetic tree for each isolate was derived from comparing sequences of $16 \mathrm{~S}$ rRNA between obtained isolates and the existing sequences in the database, using a neighbor-joining method (NJ). The NJ phylogenetic tree was divided into 2 large clades. Isolates DL2 and DL6 were grouped with B. weihenstephanensis strain PHCDB9 (NR_024697) and Pseudomonas sp. strain DSM11821 (KF417541) with a high similarity of 100 and $75 \%$, respectively (Figs. 2 and 3). Insecticidal characteristics of some Pseudomonas spp. such as $P$. entomophila, $P$. fluorescens, P. Aeruginosa, and P. chlororaphis have been investigated on coleopteran, dipteran, lepidopteran, and orthopteran pests (Osborn et al., 2002, Vodovar et al. 2005, Lednev et al., 2008 and ValletGely et al. 2010). A unique sepsis characterization resulted from infected locusts with Pseudomonas sp. was displayed as fetid smell along with disruption of internal gut (Dieppois et al., 2015). Therefore, Pseudomonas spp. may excrete enzymes or produce vegetative insecticidal protein, which interferes with receptors and disrupt the epithelial tissues in the mid-gut, therefore initiating septicaemia.

Although the insecticidal activity of $B$. weihenstephanensis has been little investigated, it showed mortalities of $80 \%$ (Sezen et al., 2007) to M. melolontha larvae and $100 \%$ to desert locust nymphs, when subjected to a cell density of $29.8 \times 10^{6}$ and $59.7 \times 10^{6}$ for leaf-dip and per os bioassay. As production of inclusion bodies or crystal protein from the present tested isolate did not recognize, it is believed that it might have the ability of producing vegetative insecticidal protein or enteric toxins such as lipase toxin phospholipase and/or paralytic toxin sphingomyelinase that occurred in Bacillus cereus (Lysenko 1972a \& b and Nishiwaki et al., 2004).

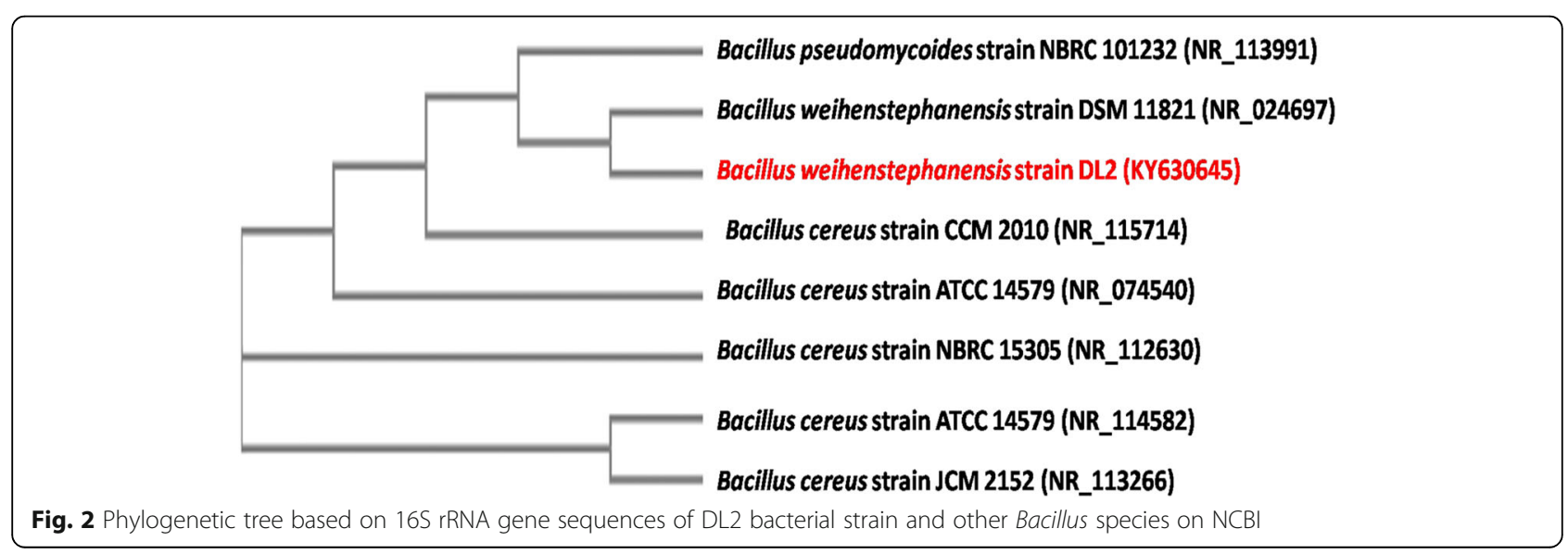




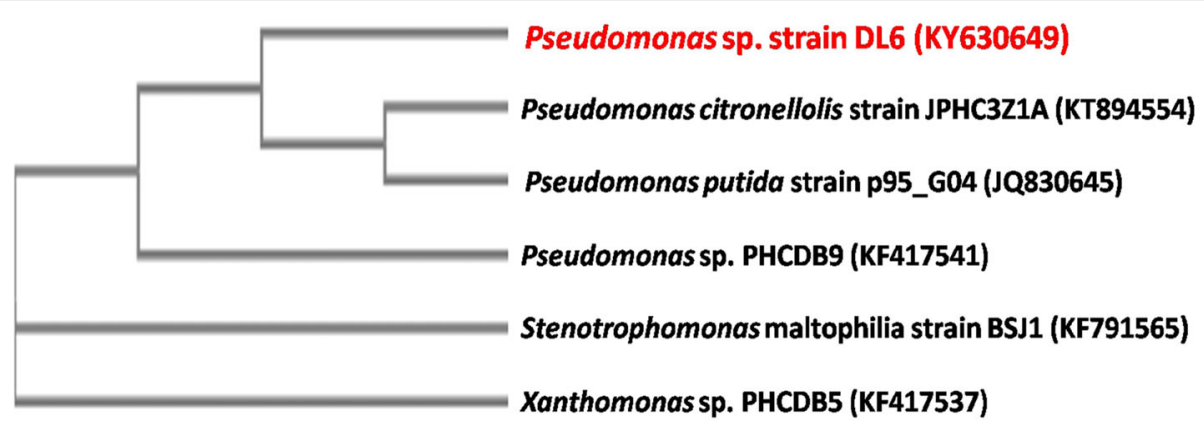

Fig. 3 Phylogenetic tree based on 16S rRNA gene sequences of DL6 bacterial strain and other closely related species on NCBI

\section{Conclusion}

Two isolated bacteria from infected locust S. gregaria nymphs in Egypt were molecularly identified as Bacillus weihenstephanensis and Pseudomonas sp. They proved the potential to be very efficient if they were formulated as biopesticide formulation and involved as a part of integrated locust management system to decrease the consuming quantities of chemical synthetic pesticides that are usually used to control locust. Further investigations are needed to characterize their mode of action and biochemical receptors involved in causing sepsis to desert locust nymphs and to test their potential against some other insect pests.

\section{Acknowledgements}

We wish to express our gratitude and deep appreciation to Profs. Yousef El Kenany and Ahmed A. Abdelhafez for offering facilities to conduct the microbiological research work in the Microbiological Resource Centre (MIRCEN) and Prof. Kadry Weshahy for offering the facilities in the bioassay lab in the Environmental Toxicology Research Unit (ETRU). We also thank Miss. Azza for technical assistance in Biolog system. This research is based on research collaboration between Environmental Toxicology Research Unit (ETRU), Plant Protection Department and Microbiological Resource Center (MIRCEN), and Department of Locust and Grasshoppers Research, Plant Protection Research Institute, Agricultural Research Centre.

\section{Authors' contributions}

TAM, MR, and AAM carried out the microbiology stuff such as isolation of the entomopathogenic bacteria from the dead/infected locusts, bacterial purification, and then preparation of the bacterial suspension in order to bioassay them. Also, they carried out the molecular identification of the promised isolates. MSE and TAM designed the experimental design, wrote the manuscript, and revised the final manuscript. AA and TAM shared the procedures of molecular identification and the sequence alignment. GMA participated with MR and TAM in the bioassay trials and statistical analysis. All authors read and approved the final manuscript.

\section{Funding}

This research did not receive any specific grant from funding agencies in the public, commercial, or non-profit sectors

\section{Availability of data and materials}

All data generated or analyzed during this study are included in this published article and the authors declare that they have no objection to the availability of data and materials.

Ethics approval and consent to participate Not applicable.
Consent for publication

Not applicable.

\section{Competing interests}

The authors declare that they have no competing interests.

\section{Author details}

'Department of Plant Protection, Faculty of Agriculture, Ain Shams University, P.O.Box: 68 Hadayek Shoubra, Cairo 11241, Egypt. ${ }^{2}$ Department of Food Science, Faculty of Agriculture, Ain Shams University, Cairo, Egypt. ${ }^{3}$ Locust and Grasshoppers Research Department, Plant Protection Research Institute, Agriculture Research Centre, Cairo, Egypt. ${ }^{4}$ Microbiological Resources Centre (MIRCEN), Faculty of Agriculture, Ain Shams University, Cairo, Egypt.

Received: 11 September 2019 Accepted: 29 October 2019

Published online: 09 December 2019

\section{References}

Al-Dhabaan FAM, Bakhali AH (2017) Analysis of the bacterial strains using Biolog plates in the contaminated soil from Riyadh community. Saudi J. Biol. Sci. 24, 901-906. doi: https://doi.org/10.1016/j.sjbs.2016.01.043. Epub 2016 Feb 1.

Aleti G, Sessitsch A, Brader G (2015) Genome mining: prediction of lipopeptides and polyketides from Bacillus and related Firmicutes. Comput. Struct. Biotechnol. J. 13:192-203. https://doi.org/10.1016/j.csbj.2015.03.003

Altschul SF, Gish W, Miller W, Myers EW, Lipman DJ (1990) Basic local alignment search tool. J. Mol. Biol. 215:729-731 https://publications.mpi-cbg.de/ Altschul_1990_5424.pdf

Ashrafi SH, Zuberi Rl, Hafiz S (1965) Occurrence of Pseudomonas aeruginosa (Schroeter) Migula as a pathogenic bacterium of the desert locust, Schistocerca gregaria (Forskal). J. Invertebr. Pathol. 7:189-191 https://kundoc. com/pdf-occurrence-of-pseudomonas-aeruginosa-schroeter-migula-as-apathogenic-bacterium-html

Barghouthi SA (2011) A universal method for the identification of bacteria based on general PCR primers. Indian J Microbiol. 51(4):430-444. https://doi.org/10. 1007/s12088-011-0122-5

Bravo A, Gómez I, Porta H, García-Gómez BI, Rodriguez-Almazan C, Pardo L, Soberón M (2013) Evolution of Bacillus thuringiensis Cry toxins insecticidal activity. Microb Biotechnol. 6(1):17-26. https://doi.org/10.1111/j.1751-7915. 2012.00342.x

Bucher GE (1981) Identification of bacteria found in insects. In: Burges HD (ed) Microbial control of pest and plant diseases. Academic Press, London, pp 10-30

Chojniak J, Jałowiecki L, Dorgeloh E, Hegedusova B, Ejhed H, Magnér J, Płaza G (2015) Application of the BIOLOG system for characterization of Serratia marcescens subsp marcescens isolated from onsite wastewater technology (OSWT). Acta Biochimica Polonica 62(4):799-805. https://doi.org/10.18388/ abp.2015_1138

COPR (Centre of Overseas Pest Research) (1982) The locust and grasshoppers Agricultural Manual, College House. Wrights lane, London, pp 310-311

Dieppois G, Opota O, Lalucat J, Lemaitre B (2015). Pseudomonas entomophila: a versatile bacterium with entomopathogenic properties. Chapter (2) In: JuanLuis Ramos, Johanna B. Goldberg and Alain Filloux (ed). Pseudomonas: New Aspects of Pseudomonas Biology. 7:25-49. 
Drancourt M, Bollet C, Carlioz A, Martelin R, Gayral JP, Raoult D (2000) 165 ribosomal DNA sequence analysis of a large collection of environmental and clinical unidentifiable bacterial isolates. J Clin Microbiol. 38(10):3623-3630 https://www.ncbi.nlm.nih.gov/pubmed/11015374

Guttmann DM, Ellar DJ (2000) Phenotypic and genotypic comparisons of 23 strains from the Bacillus cereus complex for a selection of known and putative B. thuringiensis virulence factors. FEMS Microbiology Letters. 188:713. https://doi.org/10.1111/j.1574-6968.2000.tb09160.x

Latchininsky AV, Sergeev MG, Childebaev MK, Chernyakhovsky ME, Lockwood JA, Kambulin VE, Gapparov FA (2002) Grasshoppers and locusts of Kazakhstan, Central Asia and adjacent territories. Association for Applied Acridology International and the U. of Wyoming, Laramie, WY (in Russian with English Summary)

Lechner S, Mayr R, Francis KP, Prüss BM, Kaplan T, Wiessner-Gunkel E, Stewart GS, Scherer S (1998) Bacillus weihenstephanensis sp. nov is a new psychrotolerant species of the Bacillus cereus group. Int. J. Syst. Bacteriol 48(Pt4):1373-1382. https://doi.org/10.1099/00207713-48-4-1373

Lecoq M (2001) Recent progress in desert and migratory locust management in Africa. Are preventive actions possible? J. Orthoptera Res. 10:277-291. https://doi.org/10.1665/1082-6467(2001)010[0277:RPIDAM]2.0.CO;2

Lednev GRV, Kryukov Yu, Khodyrev VP, Levchenko MA, Duisembekov BA, Sagitov AO, Glupov W (2008). Dynamics of mortality of the migratory locust under synchronous infection with entomopathogenic fungi (Beauveria bassiana, Metarhizium anisopliae) and bacteria Pseudomonas sp. Contemporary Problems of Ecology1, (2): 210-213.

Lysenko O (1972a) Pathogenicity of Bacillus cereus for insects. I. Production of phospholipase C. Folia Microbiol 17:221-227. https://doi.org/10.1007/ bf02875817

Lysenko O (1972b) Pathogenicity of Bacillus cereus for insects. II. Toxicity of phospholipase C for Galleria mellonella. Folia Microbiol 17:228-231. https://doi.org/10.1007/bf02875818

Mardanova AM, Hadieva GF, Lutfullin MT, Khilyas IV, Minnullina LF, Gilyazeva AG, Bogomolnaya LM, Sharipova MR (2017) Bacillus subtilis strains with antifungal activity against the phytopathogenic fungi. Agricultural Sciences. 8:1-20 https://pdfs.semanticscholar.org/7793/f46215ff5470434b89b7407071c1dd55 e130.pdf

Mashtoly TA, Abolmaaty A, El-Zemaity MS, Hussien MI, Alm SR (2011) Enhanced toxicity of Bacillus thuringiensis subspecies kurstaki and aizawai to black cutworm larvae (Lepidoptera: Noctuidae) with Bacillus sp. NFD2 and Pseudomonas sp. FNFD1. J. Econ. Entomol. 104(1):41-46 https://doi.org/10. 1603/EC10210

Mashtoly TA, Abolmaaty A, Thompson N, El-Zemaity MS, Hussien MI, Alm SR (2010) Enhanced toxicity of Bacillus thuringiensis japonensis strain Buibui toxin to oriental beetle and northern masked chafer (Coleoptera: Scarabaeidae) larvae with Bacillus sp. NFD2. J. Econ. Entomol 103(5):14441454 https://doi.org/10.1603/EC10028

Mashtoly TA, El-Zemaity MS, Hussien MI, Alm SR (2009) LC and LD L $_{50}$ values of Bacillus thuringiensis serovar japonensis strain Buibui toxin to oriental beetle and northern masked chafer larvae (Coleoptera: Scarabaeidae). J. Econ. Entomol. 102:1891-1895. https://doi.org/10.1603/029.102.0520

Miller JM, Rhoden DL (1991) Preliminary evaluation of Biolog, a carbon source utilization method for bacterial identification. J. Clin. Microbiol. 29(6):1143 https://www.ncbi.nlm.nih.gov/pmc/articles/PMC269959/

Nishiwaki H, Ito K, Otsuki K, Yamamoto H, Komai K (2004) Purification and functional characterization of insecticidal sphingomyelinase $C$ produced by Bacillus cereus. Eur J. Biochem 271:601-606. https://doi.org/10.1111/j.14321033.2003.03962.x

Osborn F, Berlioz L, Vitelli-Flores J, Monsalve W, Dorta B, Lemonie VR (2002) Pathogenic effects of bacteria isolated from larvae of Hylesia metabus Crammer (Lepidoptera: Saturniidae). J. Invertebr Pathol. 80:712 https://www.ncbi.nlm.nih.gov/pubmed/12234536

Reda M, Mashtoly TA, El-Zemaity MS, Abolmaaty A, Abdelatef GM (2018) Phylogenic and antagonistic characteristics of novel Bacillus cereus isolates against desert locust, Schistocerca gregaria Forskal (Orthoptera: Acrididae). Egyptian J. Biol. Pest Control. 28(51):1-7 https://ejbpc.springeropen.com/ articles/10.1186/s41938-018-0056-X

Robertson JL, Preisler HG (1992) Pesticide bioassay with arthropods. CRC Press Inc., Boca Raton, FL

SAS Institute (2012) SAS version 9.4. Cary, NC

Selvakumar G, Mohan M, Sushil SN, Kundu S, Bhatt JC, Gupta HS (2007) Characterization and phylogenetic analysis of an entomopathogenic Bacillus cereus strain WGPSB-2 (MTCC7182) isolated from white grub Anomala dimidiata (Coleoptera: Scarabaeidae). Biocontrol Sci Technol 17:525-534 https://doi.org/10.1080/09583150701311663

Sezen K, Demir I, Demirbag Z (2005) Investigations on bacteria as a potential biological control agent of summer chafer, Amphimallon solstitiale L. (Coleoptera: Scarabaeidae). J. Microbiol 43:463-468 https://www.ncbi.nlm.nih. gov/pubmed/16273040

Sezen K, Demir I, Demirbağ Z (2007) Identification and pathogenicity of entomopathogenic bacteria from common cockchafer, Melolontha melolontha L. (Col., Scarabaeidae). New Zealand J. Crop Horticul. Sci. 35:7985. https://doi.org/10.1080/01140670709510171

Sezen K, Demirbag Z (1999) Isolation and insecticidal activity of some bacteria from the hazelnut beetle (Balaninus nucum L.). App. Entomol. Zool 34(1):8589 https://doi.org/10.1303/aez.34.85

Soufiane B, Cote JC (2010) Bacillus thuringiensis serovars bolivia, vazensis and navarrensis meet the description of Bacillus weihenstephanensis. Curr Microbiol 60:343-349. https://doi.org/10.1007/s00284-009-9547-z

Sun YP (1950) Toxicity index-an improved method of comparing the relative toxicity of insecticides. J. Econ. Entomol 43:45-53 https://www.cabdirect.org/ cabdirect/abstract/19501000378

Sushil SN, Mohan M, Selvakumar G, Bhatt JC, Gupta HS (2008) Isolation and toxicity evaluation of bacterial entomopathogens against phytophagous white grubs (Coleoptera: Scarabaeidae) in Indian Himalayan hills. Int. J. Pest Manag. 54(4):301-307 https://doi.org/10.1080/09670870802187274

Swiontek Brzezinska M, Jankiewicz U, Burkowska A, Walczak M (2014) Chitinolytic microorganisms and their possible application in environmental protection. Curr. Microbiol. 68:71-81. https://doi.org/10.1007/s00284-013-0440-4

Szabo JK, Astheimer LB, Story PG, Buttemer WA (2003) An ephemeral feast: birds locusts and pesticides. Wingspan. 13:10-15

Thompson LT, Jr M, Akase E, Disterhoft JF (1994) A system for quantitative analysis of associative learning. Part 1. Hardware interfaces with cross-species applications. J Neurosci Methods 54:109-117. https://doi.org/10.1016/01650270(94)90165-1

Vallet-Gely I, Novikov A, Augusto L, Liehl P, Bolbach G, Pechy-Tarr M, Cosson P, Keel C, Caroff M, Lemaitre B (2010) Association of haemolytic activity of Pseudomonas entomophila, a versatile soil bacterium, with cyclic lipopeptides production. Appl Environ Microbiol 76(3):910-921. https://doi. org/10.1128/AEM.02112-09 Epub 2009 Dec 18

Visotto LE, Oliveira MGA, Ribon AOB, MaresGuia TR, Guedes RNC (2009) Characterization and identification of proteolytic bacteria from the gut of the velvet bean caterpillar (Lepidoptera: Noctuidae). Environ. Entomol. 38:1078-1085. https://doi.org/10.1603/022.038.0415

Vodovar N, Vinals M, Liehl P, Basset A, Degrouard J, Spellman P, Boccard F, Lemaitre B (2005) Drosophila host defense after oral infection by an entomopathogenic Pseudomonas species. Proc Natl Acad Sci U S A 102: 11414-11419. https://doi.org/10.1073/pnas.0502240102

Weisburg WG, Barns SM, Pelletier DA, Lane DJ (1991) 16 S ribosomal DNA amplification for phylogenetic study. J. Bacteriol. 173:697-703. https://doi.org/10.1128/jb.173.2.697-703.1991

\section{Publisher's Note}

Springer Nature remains neutral with regard to jurisdictional claims in published maps and institutional affiliations.

\section{Submit your manuscript to a SpringerOpen ${ }^{\circ}$ journal and benefit from:}

- Convenient online submission

- Rigorous peer review

- Open access: articles freely available online

- High visibility within the field

- Retaining the copyright to your article

Submit your next manuscript at $>$ springeropen.com 